\title{
Foliar pathogens of sweet and sour cherry in Serbia
}

\author{
Renata Iličić ${ }^{1}$, Tatjana Popović ${ }^{2}$, Slobodan Vlajić ${ }^{3}$, Vladislav \\ Ognjanov ${ }^{1}$ \\ ${ }^{1}$ Faculty of Agriculture, University of Novi Sad, Trg Dositeja Obradovića 8, \\ 21000 Novi Sad, Serbia \\ ${ }^{2}$ Institute for Plant Protection and Environment, Teodora Drajzera 9, 11040 \\ Belgrade, Serbia \\ ${ }^{3}$ Institute of Field and Vegetable Crops, Maksima Gorkog 30, 21000 Novi Sad, \\ Serbia \\ Corresponding author: renatailicic@gmail.com
}

\begin{abstract}
In recent years, sweet and sour cherry production in Serbia has increased. Under Serbian agroecological conditions, pathogens causing leaf diseases threaten the success of sweet and sour cherry production. In the period 2012-2019, the health status of cherries was monitored in more than 30 locations. Depending on the production system, the following leaf pathogens were identified: Blumeriella jaapii, Wilsonomyces carpophilus, Mycosphaerella cerasella, Phoma prunicola, Podosphaera clandestina and Pseudomonas syringae pv. syringae and morsprunorum race 1. Leaf pathogens caused premature defoliation, which adversely affected bud formation for the next growing season and increased susceptibility to freezing. Therefore, attention should be focused on correct leaf pathogen identification, and proper selection, application and rotation of fungicides.
\end{abstract}

Keywords: sweet cherry, sour cherry, leaf, disease, plant pathogenic fungi, bacteria. 


\section{Introduction}

Sweet cherry (Prunus avium L.) and sour cherry (P. cerasus L.) production is threatened by a significant number of phytopathogens affecting cherry leaves and causing premature defoliation, reduced shoot growth, increased susceptibility to winter injury, higher tree mortality, branch breakage and replanting problems.

Cherry leaf spot caused by Blumeriella jaapii (Rehm) Arx (syn. Coccomyces hiemalis Higgins; anamorph Phloeosporella padi (Lib.) Arx, syn. Cylindrosporium padi (Lib.) P. Karst. Ex Sacc.) is one of the most important and economically significant fungal pathogens affecting sweet and sour cherry both worldwide and in Serbia (Jones and Sutton, 1996; Schuster, 2004; Elmhirst, 2006; Lindhard Pedersen et al., 2012; Balaž et al., 2012; Iličić et al., 2017; 2018a). Blumeriella jaapii also affects nursery-grown stone fruits, as well as several cultivated ornamental and wild Prunus species (Jones, 1995). This pathogen primarily affects leaves, thus compromising photosynthetic ability, causing early defoliation, yield reduction and lower fruit quality. In some years, pathogen such as Wilsonomyces carpophilus (Lev.) Adaskaveg, Ogawa and Butler (previously named Stigmina carpophila (Lév.) M.B. Ellis (1959) Coryneum blight, a causative agent of shot hole disease, can cause severe damage. The disease affects buds, shoots, leaves and fruits (Ogawa and English, 1995). Cercospora leaf spot (Cercospora circumscissa Sacc. syn. C. cerasella Sacc. teleomorph Mycosphaerella cerasella Aderhold) probably has worldwide prevalence. This pathogen has been detected on sweet and sour cherry and other Prunus species (Sztejnberg, 1986; 1995). In older orchards with minimal chemical treatments used, pathogens such as Phoma prunicola (Opiz.) Wr. \& Hochapf. (syn. Phyllosticta prunicola Sacc., Phoma pomorum Thuem.) and Podosphaera clandestina (Wallr.: Fr.) Lév. can occur.

The bacterium Pseudomonas syringae can affect more than 180 plant species, including annual and perennial plants, fruit trees, ornamentals and vegetables (Agrios, 2005). Bacterial canker caused by $P$. syringae pathovars syringae and morsprunorum race 1 and 2 is one of the most serious diseases affecting stone fruit trees worldwide (Jones, 1971; Wimalajeewa and Flett, 1985; Vicente et al., 2004; Bultreys and Kaluzna, 2010; Konavko et al., 2014; Balaž et al., 2016; Iličić et al., 2017). This pathogen can attack all plant organs, including trunk, branches, leaves, fruits, flowers and buds, causing dieback. On leaves, bacterial canker pathogens cause circular lesions that fall out and produce "shot holes".

In the world fruit growing area, leaf pathogens such as Taphrina cerasi (Fuckel) Sadebeck, Apiognomonia erythrostoma (Pers.) and Monilinia kusanoi (Takahashi) Yamamoto were also described as leaf pathogens (Ogawa et al., 1995).

Disease development is mostly governed by certain weather parameters, such as temperature fluctuations, as well as averages of maximum and minimum temperatures, relative humidity and average of rainfall. If control measures are 
inadequate and conditions for leaf disease development favorable, infection will occur at much higher intensity, resulting in premature defoliation.

The aim of the present study was to determine the most common and potentially threatening leaf pathogens affecting sweet and sour cherry in the agro-ecological conditions of Serbia.

\section{Material and method}

Symptom observation and sample collection. In the period 2012-2019, monitoring of the health status of cherry plants was carried out in more than 30 locations in Serbia, including plantations, orchards with extensive and intensive production conditions, as well as cherry nurseries and wild cherry forms (Table 1).

Diseased leaves with different symptoms (spots, shot hole, powdery mildew) were collected during the spring and summer. Samples were placed in sealed plastic bags and stored in a refrigerator $\left(4^{\circ} \mathrm{C}\right)$ for $2-3$ days, until examination and/or pathogen isolation (Laboratory of Phytopathology, Faculty of Agriculture, University of Novi Sad).

Isolation. Diseased sweet and sour cherry leaves were first washed under tap water, dried on sterile filter paper and surface disinfected with alcohol. The isolation was performed on Potato Dextrose Agar (PDA), Water Agar (WA), Nutrient Agar (NA) and Nutrient Sucrose Agar (NSA). Small fragments taken from the margin of healthy and diseased tissue or formed stromata were placed onto PDA and WA for fungal isolation. For bacterial isolation, fragments were macerated in sterile distilled water (SDW), left for 20 minutes and plated on NA and NSA media. The Petri dishes were kept at $25 \pm 1^{\circ} \mathrm{C}$ for 2 to 21 days.

Diseased cherry leaves were also placed in a moist chamber for a few days for pathogen sporulation.

Identification. To identify the pathogens involved in cherry leaf diseases, standard phytopathological methods for fungal (Muntanola-Cvetković, 1987; Delibašić and Babović, 2006) and bacterial identification (Lelliott and Stead 1987; Lelliott et al. 1966; Latorre and Jones 1979; Schaad 2001) were used.

Pathogenicity tests. Healthy sweet and sour cherry leaves were artificially inoculated by spraying using the conidial conc. $10^{7} \mathrm{CFU} / \mathrm{ml}$ prepared from sporulation on naturally infected leaves in SDW and bacterial suspension conc. $10^{8} \mathrm{CFU} / \mathrm{ml}$ prepared from bacterial isolates in SDW. Control leaves were treated with distilled water. Inoculated material was kept in a plastic box on moisture filter paper at ambient temperature, until symptom development. 
Table 1. Sweet and sour cherry localities covered by monitoring

\begin{tabular}{|c|c|c|c|c|}
\hline Locality & Species & $\begin{array}{c}\text { Production } \\
\text { system }\end{array}$ & $\begin{array}{l}\text { Examination } \\
\text { period }\end{array}$ & Symptom type \\
\hline Selenča & Sweet cherry & \multirow{16}{*}{ 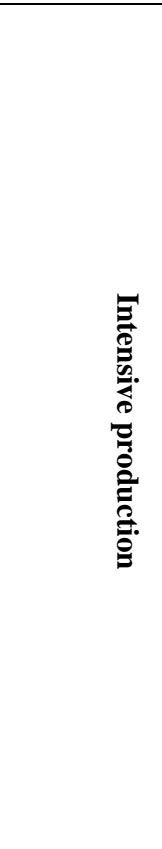 } & $2012-2019$ & $\begin{array}{l}\text { leaf spot; bacterial leaf spot and shot } \\
\text { hole }\end{array}$ \\
\hline Kać & Sweet and sour cherry & & $2012-2019$ & $\begin{array}{l}\text { leaf spot; bacterial leaf spot and shot } \\
\text { hole }\end{array}$ \\
\hline Karavukovo & Sweet cherry & & 2019 & leaf spot \\
\hline Ljutovo & Sweet cherry & & $2014-2018$ & $\begin{array}{l}\text { leaf spot; bacterial leaf spot and shot } \\
\text { hole }\end{array}$ \\
\hline Mikićevo & Sweet cherry & & $2014-2017$ & $\begin{array}{l}\text { leaf spot; bacterial leaf spot and shot } \\
\text { hole }\end{array}$ \\
\hline $\begin{array}{l}\text { Gornji } \\
\text { Tavankut }\end{array}$ & Sweet and sour cherry & & $2012-2016$ & $\begin{array}{l}\text { leaf spot; bacterial leaf spot and shot } \\
\text { hole }\end{array}$ \\
\hline Srbobran & Sweet and sour cherry & & 2018-2019 & leaf spot \\
\hline Čelarevo & Sweet cherry & & $2012-2014$ & leaf spot \\
\hline Temerin & Sweet cherry & & $2015-2018$ & - \\
\hline Sirig & Sweet and sour cherry & & $2012-2019$ & leaf spot \\
\hline $\begin{array}{l}\text { Bačka } \\
\text { Palanka }\end{array}$ & Sweet cherry & & $2012-2019$ & $\begin{array}{l}\text { leaf spot; bacterial leaf spot and shot } \\
\text { hole }\end{array}$ \\
\hline Šabac & Sweet and sour cherry & & 2016-2019 & leaf spot \\
\hline Irig & Sour cherry & & 2016-2019 & - \\
\hline Čerević & Sweet cherry & & $2015-2019$ & leaf spot \\
\hline Žitorađa & Sweet cherry & & 2018 & bacterial leaf spot and shot hole \\
\hline Vinča & Sweet cherry & & 2016 & $\begin{array}{l}\text { leaf spot; bacterial leaf spot and shot } \\
\text { hole }\end{array}$ \\
\hline $\begin{array}{l}\text { Rimski } \\
\text { Šančevi }\end{array}$ & Sweet and sour cherry & \multirow{17}{*}{ 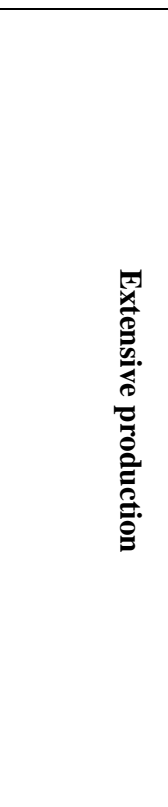 } & $2012-2019$ & leaf spot; shot hole; powdery mildew \\
\hline $\begin{array}{l}\text { Donji } \\
\text { Tavankut }\end{array}$ & Sweet and sour cherry & & $2013-2016$ & leaf spot; shot hole \\
\hline Čenej & Sweet and sour cherry & & $2015-2019$ & leaf spot; shot hole; powdery mildew \\
\hline Bođani & Sweet and sour cherry & & 2014-2019 & leaf spot; shot hole; powdery mildew \\
\hline Vajska & Sweet and sour cherry & & $2017-2019$ & leaf spot; shot hole; powdery mildew \\
\hline Novi Sad & Sweet cherry & & $2018-2019$ & leaf spot; shot hole \\
\hline Deronje & Sweet cherry & & $2016-2019$ & leaf spot; shot hole \\
\hline $\begin{array}{l}\text { Bački } \\
\text { Petrovac }\end{array}$ & Sweet and sour cherry & & $2017-2019$ & leaf spot; shot hole \\
\hline Kovilj & Sweet and sour cherry & & $2017-2019$ & leaf spot; shot hole; powdery mildew \\
\hline Bocke & Sweet and sour cherry & & $2016-2018$ & leaf spot; shot hole; powdery mildew \\
\hline Krčedin & Sweet and sour cherry & & $2015-2017$ & leaf spot; shot hole \\
\hline Ruma & Sweet cherry & & $2017-2019$ & leaf spot \\
\hline $\begin{array}{l}\text { Sremski } \\
\text { Karlovci }\end{array}$ & Sweet cherry & & 2016-2019 & leaf spot \\
\hline Bukovac & Sweet and sour cherry & & $2016-2019$ & leaf spot; shot hole \\
\hline Banstol & Sweet and sour cherry & & 2016-2019 & leaf spot; shot hole; powdery mildew \\
\hline Valjevo & Sweet cherry & & $2018-2019$ & leaf spot \\
\hline Ritopek & Sweet and sour cherry & & $2012-2019$ & leaf spot; shot hole; powdery mildew \\
\hline
\end{tabular}




\begin{tabular}{|c|c|c|c|c|}
\hline Kanjiža & Sweet and sour cherry & \multirow{2}{*}{ 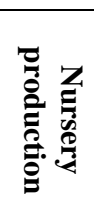 } & 2013-2014 & $\begin{array}{l}\text { leaf spot; bacterial leaf spot and shot } \\
\text { hole }\end{array}$ \\
\hline $\begin{array}{l}\text { Rimski } \\
\text { Šančevi }\end{array}$ & Sweet and sour cherry & & $2012-2019$ & leaf spot; shot hole; powdery mildew \\
\hline Fruška gora & Prunus spp. & 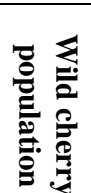 & 2016-2019 & leaf spot; powdery mildew \\
\hline
\end{tabular}

\section{Results}

Pathogen identification and distribution. During the study period (2012-2019), the intensity of foliar diseases of cherries in Serbia increased. Leaf spot and shot hole symptoms were manifested during the spring and summer, depending on the pathogen present and the system of production (Figure 1).

All fungal foliar pathogens proved extremely difficult to isolate on the mentioned nutrient media. Identification of fungal pathogens was performed from sporulation (microscopic characteristics) on leaves placed in a moist chamber. Bacterial pathogens were successfully isolated from the symptomatic leaves collected in May and June. Based on the obtained results, leaf pathogens affecting sweet and sour cherry leaves in Serbia were the phytopathogenic fungi B. jaapii, W. carpophilus, M. cerasella, P. prunicola and P. clandestina and the bacteria Pseudomonas syringae pvs. syringae and morsprunorum race 1 (Figure 1). Symptoms of mentioned leaf pathogens are shown in Figure 2. Compared to sour cherry, sweet cherry was more susceptible to all examined fungal and bacterial leaf pathogens.

Blumeriella jaapii. Cherry leaf spot caused by B. jaapii is still one of the most important fungal diseases affecting sweet and sour cherry leaves. This pathogen was identified in orchards receiving reduced, inadequate chemical treatment (intensive, extensive production) or on unsprayed trees. Its presence was also confirmed in sweet and sour cherry nursery production as well as on wild cherry forms. B. jaapii symptoms occurred in early summer on the upper surface of leaves, as tiny, red to purple circular spots that enlarged and turned red-brown to brown. In the spot center on the leaf underside, light pink to white masses from slightly concave eruptions (acervuli) emerged with hyaline, elongated, curved or flexuous, with one or two septe conidia, causing secondary infection. Diseased leaves turned yellow, fell off the tree and severely affected the trees, which defoliated by midsummer. Defoliation made the trees susceptible to winter frost, especially in the case of young trees. In diseased trees, weak fruit buds, reduced shoot growth and death of fruit spurs were also common. 
Differences in cultivar susceptibility to this pathogen were also noted (unpublished data).
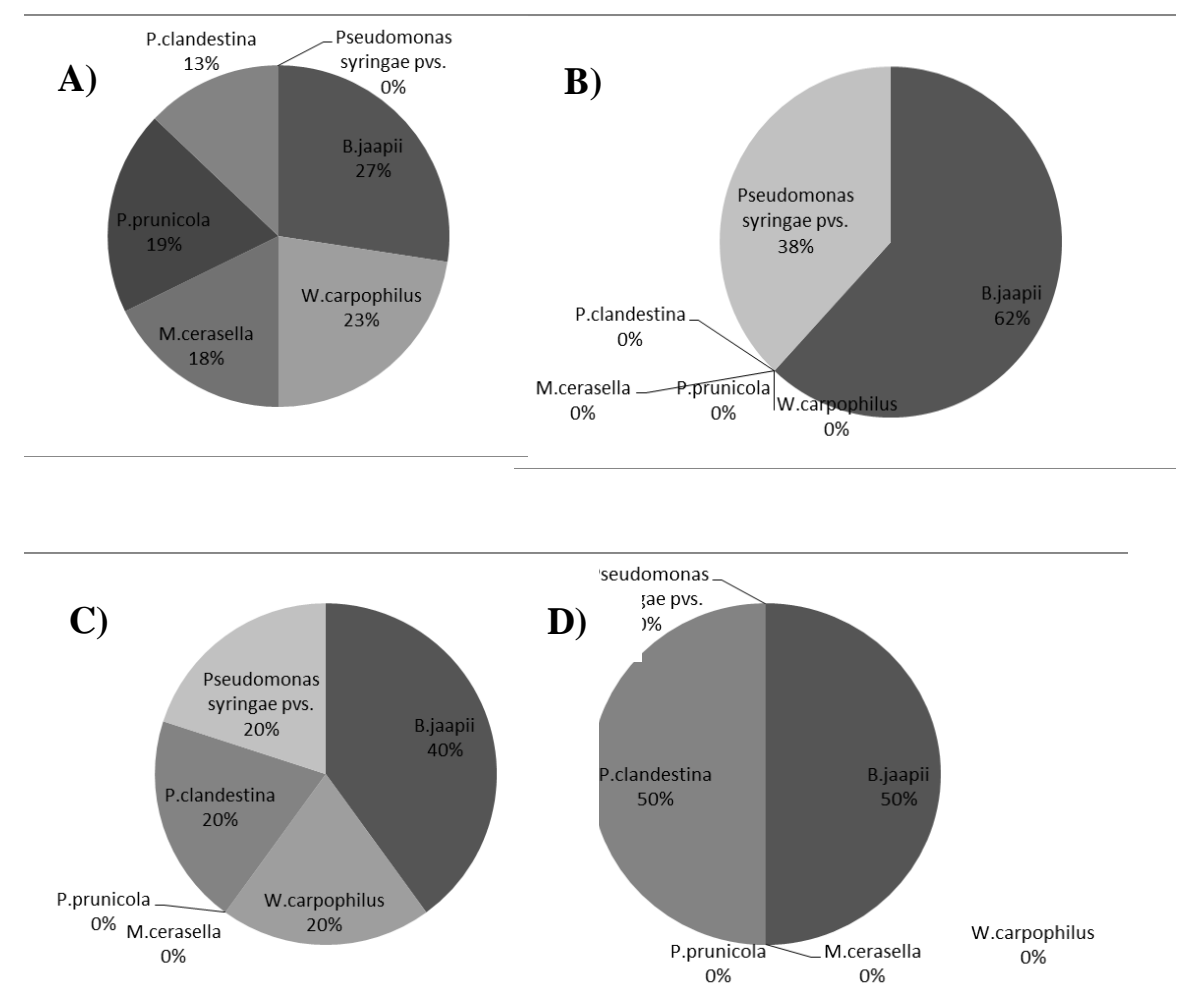

Figure 1. Distribution of cherry leaf pathogens in: A) extensive production; B) intensive production; C) nursery production; D) wild cherry population

Wilsonomyces carpophilus - S. carpophila. The causative agent of shot hole disease caused severe damage, especially when no dormant spray was applied (extensive and nursery production). Treatment with copper fungicides significantly reduced the amount of inoculum and prevented the occurrence of infections. In the present study, the first disease symptoms were observed on young leaves in the form of small red areas that expanded and became larger, irregular, reddish-brown to purple with a yellow halo border surrounding a white center. Spots dropped out, leaving a shot hole appearance, eventually causing the entire leaves to drop. The conidia of $S$. carpophila were ovoid, brown and dry, and were characterized by 2-5 thick dark brown cross walls (septa). In a few cases, spots on fruits sagged until the pit was revealed. S. carpophila disease symptoms are similar to those of bacterial leaf spot caused by Pseudomonas syringae pvs. 

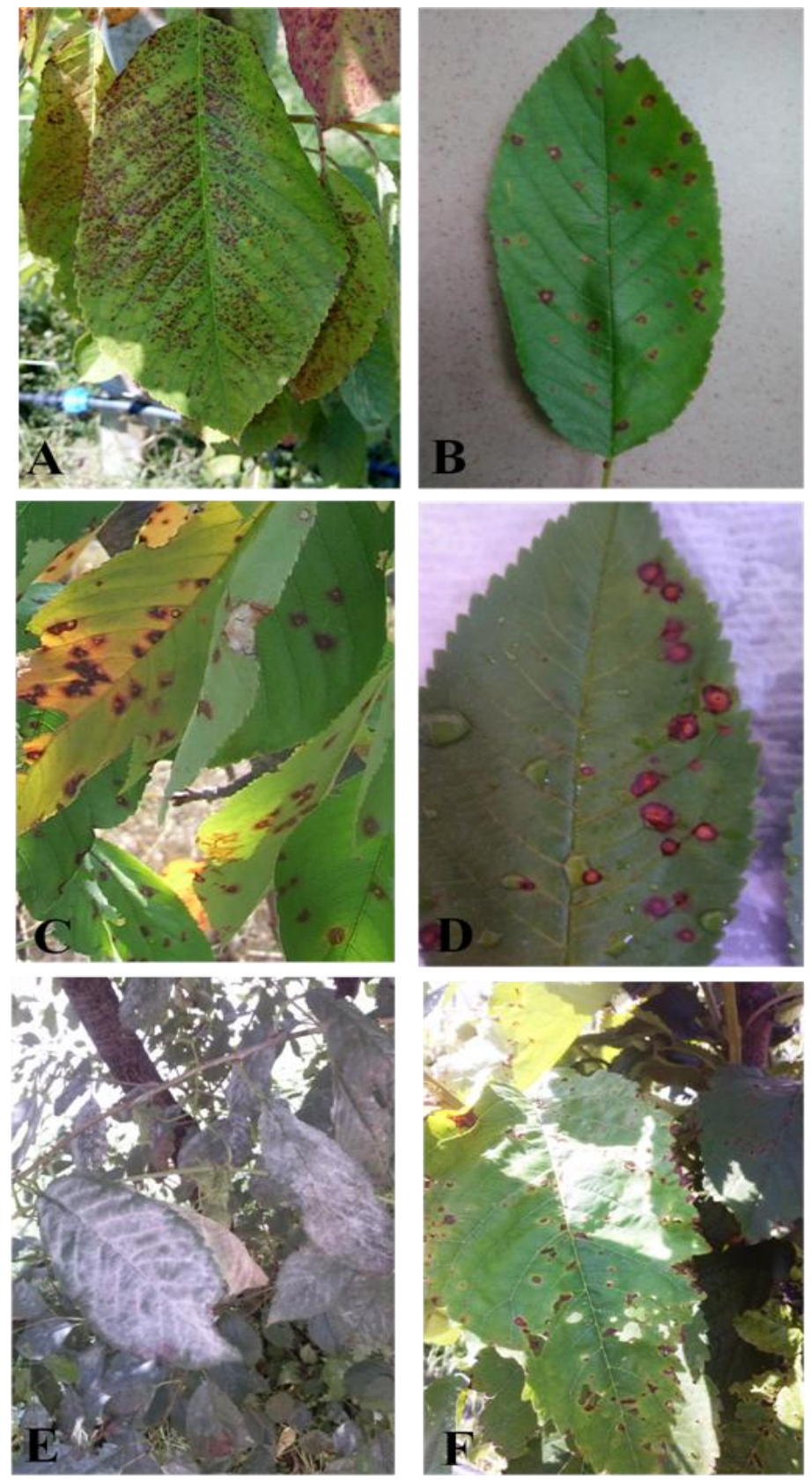

Figure 2. Symptoms on cherry leaves caused by: A - Blumeriella jaapii; B Wilsonomyces carpophilus; C - Mycosphaerella cerasella; D - Phoma prunicola; E - Podosphaera clandestina; F - Pseudomonas syringae pvs. (Iličić R.) 
Mycosphaerella cerasella - C. cerasella. Under extensive cherry production conditions, the presence of the pathogen $M$. cerasella $-C$. cerasella was detected. Disease symptoms emerged at the time of the occurrence of B. jaapii. Spots were initially round, reddish to brown and their size gradually increased, and the center turned light brown with brownish red edges. On a few occasions, spots coalesced into necrotic patches. Only the conidial stage was found; long, curved, olivaceous and septate conidia formed on brown, geniculate, flexuose conidiophores.

Phoma prunicola. In early summer during the investigated period, the pathogen $P$. prunicola was also found in unsprayed orchards. Initially, spots were small, with a white center, but expanded rapidly and turned reddish to brown with brownish red edges (with a spot diameter of 4-8 $\mathrm{mm}$ ). In the spot center, the pathogen formed pycnidia with pycnidiospores (single-celled, oval to elliptic).

Podosphaera clandestina. In some years, in extensive production, nursery production or on individual trees, in gardens and yards, as well as on wild cherry forms, the presence of powdery mildew on leaves caused by P. clandestina was noted. Circular white lesions (fungal mycelium and conidia-oidia) on the surface of young leaves were observed, while no symptoms emerged on fruits. In early summer, cleistothecia also developed.

Pseudomonas syringae pvs. (syringae and morsprunorum race 1). In intensive (young) cherry plantations and orchards, in which control measures are adequate (timely and repeated fungicide applications), diseases caused by phytopathogenic fungi are usually not a problem, except in the case of $B$. jaapii (mid to late August). However, the two P. syringae pathovars (syringae and morsprunorum race 1) identified as part of the present study were problematic, as they are the causal agents of bacterial dieback and leaf spots in cherries. Spots and shot holes were observed on cherry leaves in May and June. Spots were initially water-soaked and then became brown-purple, round to angular, surrounded by yellow halos. Due to the development of numerous spots on leaves, centers of the necrotic spots dropped out, giving the leaf a shot hole appearance. Under favorable conditions (rainy and cold weather), the disease spread rapidly, often affecting the leaves of the entire crown.

Pathogenicity tests. To confirm that the studied pathogens caused symptoms on sweet and sour cherry, artificial leaf inoculation in laboratory conditions was performed. In the case of fungal leaf pathogens, the first symptoms occurred 7 to 10 days after inoculation, and all tested pathogens caused symptoms similar to those on naturally infected leaves. Bacterial leaf pathogens on the inoculated leaves caused symptoms after 3 to 4 days. Leaves inoculated with SDW were symptomless. 


\section{Discussion}

In order to determine the most common and potentially threatening pathogens in sour and sweet cherry production in the agro-ecological conditions of Serbia, in this study we observed some major characteristics of the leaf pathogens determined.

The most destructive and most widely distributed foliar pathogen of sweet and sour cherry was B. jaapii (Table 1). The occurrence of this disease in intensive and extensive plantations was certainly caused by climate change (factors favoring sporulation, spore dispersal, germination and penetration), inadequate chemical control and increased susceptibility of sweet and sour cherry cultivars (Iličić et al., 2017; 2018a). In intensive production, despite proper control practices, the presence of the pathogen was determined in mid to late August. This indicates that, despite the classical use of fungicides, great attention should be paid to the anti-resistance strategy related to

the combined application of fungicides with different mechanisms of action. It is also important to emphasize that the production of a large amount of secondary inoculum is also crucial for the severity of the disease (Outwater 2014). B. jaapii was an important pathogen for sweet and sour cherry nursery production; in young plants defoliation occurred in mid-summer, as reported earlier by Jones (1995) and Balaž et al. (2012). The fungal leaf pathogens $W$. carpophilus, M. cerasella, P. prunicola and P. clandestine were also recorded. They were present in orchards with minimized chemical control (extensive production), on unsprayed trees, in nurseries and on wild cherry forms. In intensive cherry plantations and orchards $P$. syringae pathovars causing bacterial leaf spot are becoming a major problem. Factors that contribute to the occurrence and spread of these pathogens are latently infected planting material, new cultivars, rootstocks, new technology of cherry production as well as the epiphytic nature of the pathogen (Iličić et al., 2018b).

To prevent all foliar diseases in cherries, it is recommended to apply two autumn sprays of copper-based fungicides to reduce the infectious potential and epiphytic population, and one spray in early spring, before bud break. Two to three pre-harvest and 3-5 post-harvest treatments are necessary, especially if spring and summer are rainy. For this purpose, fungicides based on captan, mancozeb, difenoconazole, tebuconazole, dodine, prochloraz, thiophanate methyl, dithianon and chlorothalonil are used to protect against fungal leaf pathogens.

All phytopathogens examined in the present study cause premature defoliation and reduce the number of formed buds and fruit yield in the following year. Moreover, the affected trees become more susceptible to frost and low winter temperatures, which increases tree mortality. Timely and correct pathogen identification is thus necessary for appropriate disease management. 


\section{Acknowledgments}

This work was supported by the Serbian Ministry of Education, Science and Technological Development, Project No. TR31038 "Selection of sweet and sour cherry dwarfing rootstocks and development of intensive cultivation technology based on the sustainable agriculture principles".

\section{References}

Agrios G.N. (2005): Plant Pathology, Fifth Edition. Elsevier Academic Press, University of Florida.

Balaž J., Iličić R., Ognjanov V., Ivanović Ž., Popović T. (2016): Etiology of bacterial canker on young sweet cherry trees in Serbia. Journal of Plant Pathology, 98 (2): 285-294.

Balaž J., Ognjanov V., Iličić R., Grahovac M. (2012): Important mycoses and bacterioses of sweet cherry. Plant Doctor, 40 (4): 316-335.

Bultreys A., Kaluzna, M. (2010): Bacterial cankers caused by Pseudomonas syringae on stone fruit species with special emphasis on the pathovars syringae and morsprunosrum race 1 and race 2. Journal of Plant Pathology 92: (1, Supplement): 21-33.

Delibašić G., Babović M. (2006): Opšta fitopatologija-Praktikum. Univerzitet u Beogradu, Poljoprivredni fakultet. Akademska misao, Beograd.

Elmhirst J. (2006): Crop Profile for Sweet Cherries in Canada. Pesticide Risk Reduction Program, Pest Management Centre. Agriculture and Agri-Food Canada.

Iličić R., Vlajić S., Maširević S., Stošić N., Ljubojević M., Ognjanov V. (2017): Pathogens of sweet and sour cherry leaves in Serbia. $3^{\text {rd }}$ International symposium for agriculture and food - ISAF, 18-20 October, Ohrid, Republic of Macedonia, 381.

Iličić R., Vlajić S., Ljubojević M., Barać G., Dulić J., Miodragović M., Ognjanov V. (2018a): Reaction of different sweet and sour cherry genotypes against Blumeriella jaapii (Rehm) v. Arx). Simpozijum Sekcije za oplemenjivanje organizama Društva genetičara Srbije i IX Simpozijum Društva selekcionera i semenara Republike Srbije, Vrnjačka Banja 7-11. maj, 159-160.

Iličić R., Balaž J., Ognjanov V., Jošić D., Vlajić S., Ljubojević M., Popović T. (2018b): Evaluation of cherry cultivar susceptibility to bacterial canker and leaf spot disease. Journal of Phytopathology, 166:799-808.

Jones A.L. (1971): Bacterial canker of sweet cherry in Michigan. Plant Disease Reporter, 55: 961-965.

Jones A.L., Sutton T.B. (1996): Diseases of Tree Fruits in the East. Michigan State University.

Jones L.A. (1995): Cherry leaf spot. In Ogawa J.M., Zehr E. I., Bird G.W., Ritchie D.F., Uriu K. Ujemoto J.K. (eds), Compendium of Stone fruit diseases, APS Press, pp. 2122.

Konavko D., Moročko-Bičevska I., Bankina B. (2014): Pseudomonas syringae as important pathogen of fruit trees with emphasis on plum and cherry. Annual $20^{\text {th }}$ International Scientific Conference Proceedings, Latvia University of Agriculture, Research for Rural Development, 19-25. 
Latorre B.A., Jones A.L. (1979): Pseudomonas morsprunorum, the cause of bacterial canker of sour cherry in Michigan and its epiphytic association with P. syringae. Phytopathology, 69: 335-339.

Lelliott R.A., Stead, D.E. (1987): Methods for the diagnosis of bacterial diseases of plants. Oxford, London, Edinburgh, British Society for Plant Pathology, Blackwell Scientific Publications.

Lelliott R.A., Billing E., Hayward A.C. (1966): A determinative scheme for the fluorescent plant pathogenic Pseudomonads. Journal of Applied Bacteriology, 29 (3): 470-489.

Lindhard Pedersen H., Jensen B., Munk L., Bengtsson M., Trapman, M. (2012): Reduction in the use of fungicides in the apple and sour cherry production by preventive methods and warning systems. Pesticides Research 139.

Muntanola-Cvetković M. (1987): Opšta mikologija. Književne novine, Beograd.

Ogawa J.M., English H. (1995): Shot Hole. In Ogawa., J. M., Zehr, E. I., Bird, G.W., Ritchie, D. F., Uriu, K. and Ujemoto, J. K. (eds), Compendium of Stone fruit diseases, APS Press, pp. 10-11.

Outwater C.A. (2014): Detection of boscalid resistance and the H272R mutation in the SDHB gene of Blumeriella jaapii. Michigan State University in partial fulfillment of the requirements for the degree of Plant Pathology - Master of Science.

Schaad N.W. (2001): Laboratory Guide for Identification of Plant Pathogenic Bacteria, Third Edition, APS Press.

Schuster M. (2004): Investigation on resistance to leaf spot disease (Blumeriella jaapii), in cherries. Journal of Fruit and Ornamental Plant Research, 12: 275-279.

Sztejnberg A. (1986): Etiology and control of cherry leaf disease in Israel caused by Cercospora circumscissa. Plant Disease, 70: 349-351.

Sztejnberg A. (1995): Cercospora Leaf Spot. In Ogawa. J.M., Zehr E.I., Bird G.W., Ritchie D.F., Uriu K., Ujemoto J.K. (eds), Compendium of Stone fruit diseases, APS Press, pp. 27.

Vicente J.G., Alves J.P., Russell K. (2004): Identification and Discrimination of Pseudomonas syringae Isolates from Wild Cherry in England. European Journal of Plant Pathology, 110: 337-351.

Wimalajeewa D.L.S., Flett J.D. (1985): A study of populations of Pseudomonas syringae pv. syringae on stone fruits in Victoria. Plant Pathology, 34: 248-254. 


\section{PATOGENI LISTA TREŠNJE I VIŠNJE U SRBIJI}

\section{Renata Iličić ${ }^{1}$, Tatjana Popović ${ }^{2}$, Slobodan Vlajić ${ }^{3}$, Vladislav Ognjanov ${ }^{1}$}

${ }^{1}$ Poljoprivredni fakultet, Univerzitet u Novom Sadu, Trg Dositeja Obradovića 8, 21000 Novi Sad, Srbija

${ }^{2}$ Institut za zaštitu bilja i životnu sredinu, Teodora Drajzera 9, 11040 Beograd, Srbija

${ }^{3}$ Institut za ratarstvo i povrtarstvo, Maksima Gorkog 30, 21000 Novi Sad, Srbija

\section{Rezime}

Poslednjih godina proizvodnja trešnje i višnje u Srbiji je povećana. U našim agroekološkim uslovima, patogeni lista ugrožavaju proizvodnju ovih perspektivnih voćnih vrsta. U periodu 2012-2019. godine praćeno je zdravstveno stanje trešnje i višnje, na više od 30 lokaliteta. Zavisno od sistema proizvodnje identifikovani su sledeći patogeni lista: Blumeriella jaapii, Wilsonomyces carpophilus, Mycosphaerella cerasella, Phoma prunicola, Podosphaera clandestina, Pseudomonas siringae pv. syringae i morsprunorum rasa 1. Patogeni lista izazivaju prevremenu defolijaciju, što negativno utiče na formiranje pupoljaka za narednu vegetaciju i povećanu osetljivost na izmrzavanje. Stoga pažnju treba usmeriti na ispravnu identifikaciju patogena, pravilan izbor i rotaciju fungicida različitog mehanizma delovanja, kao i optimalno vreme za njihovu primenu.

Ključne reči: trešnja, višnja, list, bolest, fitopatogene gljive, bakterije. 